\title{
Clinical pharmacology and therapeutics
}

\author{
Richard C. Horton and Martin J. Kendall \\ Department of Medicine, Queen Elizabeth Hospital, Birmingham B15 2TH, UK
}

\section{Introduction}

Drug therapy continues to change and, in some areas, improves. Clinical trials are larger, requirements of trialists are more demanding, and the commercial consequences of the results are enormous. Trialists who devise an initial protocol must therefore ask the right question, select the correct patients, and seek answers that are still relevant when the results finally become available. These requirements are not always attained.

When a large clinical trial fails to give an unambiguous answer, there is now an increasing tendency to collect results from many studies and to complete a meta-analysis. The results of these are presented as authoritative answers to specific questions. But this quest for statistical truth has introduced a facade of mathematical acceptability that risks drawing the clinician away from reality. Trials are experiments that examine specific questions. Meta-analyses are not experiments; they are simply observational studies and as such are susceptible to the inherent biases of all observations. A meta-analysis includes trials that frequently do not ask the same questions. A.E. Houseman, the English classical scholar and poet, wrote that "criticism is not a branch of mathematics, nor indeed an exact science at all. A critic engaged upon his business is not like Newton investigating the motions of the planets'.

Progress is also being made on improving our understanding of pathophysiological processes. In 3 therapeutic areas, increasing knowledge of mechanisms is leading to more rational therapeutic approaches. In this review, we have chosen to take note of these developments and to try to outline their impact on cardiac arrhythmias, gastroenterological disorders, and a broad group of neuropsychiatric conditions. Some of the new developments in these areas are being and will be translated into worthwhile therapeutic advances.

Correspondence: M.J. Kendall, M.D., F.R.C.P.

\section{Cardiovascular pharmacology}

The subtleties and nuances that underlie the diagnosis and treatment of cardiac arrhythmias are largely within the province of cardiologists. However, there are two instances where the general physician might consider giving an antiarrhythmic drug: in the treatment of an acute arrhythmia and after myocardial infarction. The clinical judgement about which agent to select is not helped by the complex electrophysiological classifications of 웅 antiarrhythmic agents that exist. A functional classification is adopted in our discussion.

\section{Acute termination of arrhythmias}

Paroxysmal supraventricular re-entrant tachyca: dia (SVT) is usually rapidly terminated with intras venous verapamil. The United States Food an Drug Administration recently approved adenosine as an alternative drug to treat SVT. ${ }^{1}$ Both agents have poor efficacy in atrial and ventricular arrhythmias, but are successful in over $90 \%$ of cases of SVT. Although adenosine has some theoretical advantages (short duration of action and lack of adverse effect in patients with either pre-excitation SVT or ventricular tachycardia (VT) misdiagnosed as SVT with aberrant conduction), the lack of large randomized trials prevents a judgment about the relative effects of these two drugs.

Haemodynamically stable ventricular tachycardia (VT) should still be treated initially with lignocaine. ${ }^{2}$ This drug proved to be the safest when compared with adenosine, disopyramide, flecainide, and sotalol. Disopyramide is probably the second-line treatment of choice for VT.

\section{Post-myocardial infarction}

Potentially life-threatening arrhythmias after $\tilde{O}$ myocardial infarction have led to attempts at $\stackrel{\mathrm{N}}{N}$ antiarrhythmic prophylaxis. However, something $\underset{2}{2}$ of a cloud has descended over this subject since publication of data from the Cardiac Arrhythmia Suppression Trial (CAST). ${ }^{3}$ The assumption that symptomless ventricular arrhythmias could act as a surrogate marker for sudden death has been pro- 
ven to be false. Moreover, treatment with flecainide and encainide actually increased mortality (relative risk 3.6). Subsequent analysis of these data suggested that flecainide and encainide may induce an arrhythmogenic ischaemic myocardium. ${ }^{4}$

Only $\beta$ blockers are able to reduce mortality from sudden death after an infarct. Indeed, evidence now points to adrenergic arrhythmogenicity as the main cause of post-infarction arrhythmias. For this reason, propafenone $-\mathbf{a}$ class Ic agent, like flecainide and encainide, and a weak $\beta$ blocker - holds great promise. ${ }^{5}$ This drug suppresses both supraventricular and ventricular arrhythmias. The potential value of propafenone is drawn attention to by an excellent meta-analysis-cum review of clinical trials of this agent in malignant ventricular arrhythmias such as sustained VT and non-infarct related ventricular fibrillation (VF). ${ }^{6}$ Hernandez et al. concluded that propafenone was both safe and effective; a combined efficacy rate of $61 \%$ was calculated for patients who had failed on between 2 and 4 other antiarrhythmic drugs. Care must be taken in patients with severe heart failure and proarrhythmic actions have been reported. Moreover, propafenone increases serum digoxin concentrations and prolongs prothrombin time. Co-administration of cimetidine leads to increases in circulating concentrations of this antiarrhythmic drug. Further trials are needed to assess propafenone's efficacy after myocardial infarction.

Conventional $\beta$ blockers also have an influence on VF. Clinical evidence that metoprolol, ${ }^{7,8}$ propranolol, ${ }^{9}$ and timolol $^{10}$ all reduce the risk of sudden death in patients post-myocardial infarction is well documented. These data have now been linked with the capacity of $\beta$ blockers to reduce the frequency of malignant ventricular arrhythmias. VF occurs on a background of increased sympathetic drive, decreased vagal tone, and myocardial ischaemia. This has led to interest in the cerebral effects of lipophilic $\beta$ blockers. Parker and colleagues ${ }^{11}$ have injected low doses of propranolol into the cerebral ventricles of pigs submitted to coronary occlusions and stress. In this model, the frequency of VF was reduced. Dellsperger et al. ${ }^{12}$ compared rates of VF in 4 groups of dogs: a control group and 3 others that developed left ventricular hypertrophy (LVH) after unilateral nephrectomy and partial occlusion of the other renal artery. One group with LVH was left untreated, the second was given metoprolol to lower blood pressure, and the third group was given enalapril. VF rates were highest $(65 \%)$ in the untreated LVH group, but were $53 \%$ with enalapril, $17 \%$ with metoprolol, and $27 \%$ in the randomized controls. Finally, Ablad and colleagues ${ }^{13}$ have used a rabbit model anaesthetized with chloralose to increase sympathetic drive. These animals were treated with metoprolol, atenolol, or saline. Both metoprolol and atenolol reduced sympathetic drive, blood pressure, heart rate, and infarct size. However, metoprolol was associated with maintained or increased vagal tone and this was associated with a lower VF rate: metoprolol $4 / 12$, atenolol $10 / 12$, and controls $11 / 12$.

Moricizine is a drug developed in the USSR and now approved by the US Food and Drug Administration for oral treatment of life-threatening ventricular arrhythmias. ${ }^{14}$ Early trials suggested that moricizine is probably more effective than either disopyramide or propranolol. However, although CAST continued to evaluate moricizine, this trial was stopped in August 1991 after the data monitoring committee noted a trend towards increased mortality in the treatment group.

Out of this uncertainty comes some order. Burkart and colleagues have now reported data from the Basel Antiarrhythmic Study of Infarct Survival (BASIS). ${ }^{15}$ They randomized over 300 patients to individualized antiarrhythmic therapy, low-dose amiodarone, or no treatment. After 12 months, intention-to-treat analysis showed a significant survival benefit in the amiodarone group. Side effects were limited although they remain a source of concern if long-term treatment is required.

\section{Gastroenterology}

The atmosphere among gastroenterologists has become noticeably more tense over the last 18 months as pharmaceutical companies have attempted to settle old scores, open up new avenues for research, and seek new indications for old products. How successful have these developments been?

\section{Reflux oesophagitis}

Any treatment must aim to reduce and neutralize reflux contents, enhance oesophageal clearance, and protect oesophageal mucosa. Drugs are required when simple measures fail. Omeprazole is now indicated as a second or third line agent for ulcerative oesophagitis; ${ }^{16}$ it is not licensed for maintenance therapy. Despite the impressive healing rates attributable to this proton-pump inhibitor ( $71 \%$ at 8 weeks with omeprazole $40 \mathrm{mg} / \mathrm{day}),{ }^{17-19}$ relapse rates have not been correspondingly reduced. Moreover, concern has been raised about reversible side effects (diarrhoea, skin reactions, and headache ${ }^{20}$ that often necessitate drug withdrawal. Reports by Glaxo - the manufacturers of ranitidine - that omeprazole caused unscheduled DNA synthesis, and was therefore genotoxic, have been largely discredited. ${ }^{21}$

Cisapride - a prokinetic agent that promotes 
acetylcholine release in the myenteric plexus - is as effective as cimetidine in both alleviating symptoms of and healing mild oesophagitis. ${ }^{22}$ There is little evidence of additional therapeutic benefit when cisapride is compared with either $\mathbf{H}_{2}$-receptor antagonists or metoclopramide. ${ }^{23}$ New liquid formulations of existing $\mathrm{H}_{2}$-receptor antagonists have few data to commend them. ${ }^{24}$ Short-term improvements in symptoms of reflux have been found with an oral combination of cimetidine and alginic acid when compared with cimetidine alone. ${ }^{25}$

\section{Peptic ulcer disease}

Further refinement of the indications for $\mathrm{H}_{2-}$ antagonists has been reported. Patients with duodenal ulcers who smoke relapse faster than non-smokers. When ranitidine $150 \mathrm{mg}$ nocte is compared with ranitidine $300 \mathrm{mg}$ nocte, cumulative ulcer recurrence rates at 18 months were nearly twice as great with the lower dose. ${ }^{26}$ Reports of omeprazole's efficacy continue to put pressure on licensing authorities to extend its indication beyond that of a second-line agent for resistant peptic ulceration for which it has a proven benefit above that of $\mathrm{H}_{2}$ antagonists. ${ }^{27}$ Symptomatic relief is greater ${ }^{28}$ and faster ${ }^{28,29}$ when omeprazole is compared with ranitidine. A UK licence to cover first-line therapy is expected to be granted in 1992.

A double-blind trial of omeprazole for 3 days a week as maintenance therapy in treated duodenal ulcer patients showed a $23 \%$ recurrence rate at 6 months compared with $67 \%$ for those taking placebo. ${ }^{30}$ Such intermittent therapy may obviate concerns about regular long-term maintenance treatment.

Helicobacter pylori seems to have a direct causal influence in duodenal ulcer disease. Rauws and colleagues showed a 12 month disease-free period among 17 of 45 patients who had intractable duodenal ulcer and who completed a 4 week regimen of amoxycillin, metronidazole, and colloidal bismuth subcitrate. ${ }^{31}$ In these 17 patients, $H$. pylori was eradicated. Omeprazole may have an important modifying effect on gastritis associated with $H$. pylori and has been shown to eradicate $H$. pylori in $56 \%$ of patients; both gastritis and duodenal ulcer are healed in these subjects. ${ }^{32}$

Misoprostol has no advantage over $\mathrm{H}_{2}$ antagonists in the treatment of benign peptic ulcer. ${ }^{33}$ However, non-steroidal anti-inflammatory drug (NSAID)-induced gastric ulceration does benefit from misoprostol therapy, whereas $\mathrm{H}_{2}$-antagonists have little effect. It is probably reasonable to give prophylactic misoprostol to patients taking NSAIDS who have a previous history of gastric ulcer. This policy is likely to be cost effective. ${ }^{34}$ However, misoprostol's effects on ulcer healing and symptom control during longer term NSAID use remain to be established. ${ }^{35}$ Misoprostol must be avoided in young women who do not use regular contraception. ${ }^{36}$

\section{Motility disorders}

Methodological difficulties have limited the study of gut motility disorders. However, functional $\overline{\frac{\omega}{5}}$ bowel disease affects up to $15 \%$ of the population $\widehat{\nabla}$ and motility disturbances, together with autonomic dysfunction, may be the cause of these ${ }^{\infty}$ symptoms. ${ }^{37,38}$ Although physiological under- $\vec{O}$ standing of functional bowel disorders remains $\overrightarrow{-}$ rudimentary, important therapeutic advances have ${ }_{\sigma}^{\omega}$ taken place. Erythromycin stimulates small bowel $\overline{0}$ activity and promotes gastric emptying in both $\frac{0}{3}$ diabetic gastroparesis ${ }^{39}$ and postvagotomy gastric stasis. ${ }^{40}$ Erythromycin seems to act in a way that. parallels motilin, a neuropeptide in the enteric 0 o nervous system. Laboratory animal studies show that in 2 day old rabbit gut, when no motilin receptors are present, neither erythromycin nor $N$ motilin had any effect on intestinal contractility. ${ }^{41} \stackrel{\text { ㅇ }}{\longrightarrow}$ Prokinetic effects of erythromycin were found only when motilin receptors became detectable. Both ${ }_{\mathbb{D}}$

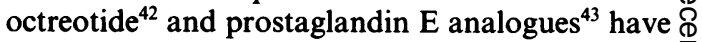
prokinetic effects on gut and these agents deserve $\bar{Z}$ further clinical study in functional bowel disease $\frac{\Phi}{-}$

An open randomized trial has confirmed the $\vec{\theta}$ efficacy of mebeverine and dietary fibre in the 6 treatment of irritable bowel syndome. ${ }^{44}$ In const pation-prone patients with irritable bowel, cisapride significantly increased stool output compared with placebo. ${ }^{45} \mathrm{~A}$ total of $71 \%$ of patients rated their treatment response as good or excellent.

\section{Inflammatory bowel disease}

Systemic steroid treatment in patients with Crohn's disease has been limited by the high frequency of $\bar{\partial}$ side effects. Fluticasone propionate, a new topically active agent with poor systemic absorption after oral dosing and a high first-pass metabolism, offers the possibility of overcoming these difficulties. A pilot study has confirmed this drug's efficacy both clinically and by indium-labelled white-cell scans. ${ }^{46}$ Randomized trials are awaited.

New 5-aminosalicylic acid (5-ASA-mesalazine and olsalazine) preparations continue to threaten sulphasalazine as the drug of first choice for maintenance treatment in ulcerative colitis. ${ }^{47}$ Olsalazine $\widetilde{N}$ has proven superiority over sulphasalazine ${ }^{48}$ but ${ }_{\mathrm{N}}$ few data are yet available that compare mesalazine with olsalazine. However, olsalazine does have 0 pharmacokinetic advantages over its 5-ASA competitors, ${ }^{49}$ and a single abstracted report ${ }^{50}$ suggests ? significant differences in relapse rates among patients receiving olsalazine compared with those 
receiving mesalazine. Both of these preparations are far more costly than sulphasalazine.

\section{Therapeutics in liver disease}

The efficacy of treatment of acute variceal haemorrhage with vasoactive agents remains confused. Although vasopressin and nitrates have similar effects on survival compared with balloon tamponade, drug therapy has been associated with an increased frequency of failures and rebleeds. ${ }^{51}$ Treatment of portal hypertension in cirrhotic patients with varices has two main end-points: reduction in mortality in either those who have not had a first bleed or in those who have. A metaanalysis of trials to prevent variceal haemorrhage confirms a survival advantage in those treated with propranolol. ${ }^{52}$

Bile acid therapy for cholestatic liver disease now seems a real possibility. Ursodeoxycholic acid (UDCA) lowers the detergent properties of bile and may therefore reduce its toxicity to hepatocytes. Liver enzymes are reduced by UDCA in cholestatic liver diseases, ${ }^{53}$ and histological improvements have been reported in patients with primary biliary cirrhosis. ${ }^{54}$ Cyclosporin seemed to benefit a small number of patients with primary biliary cirrhosis, ${ }^{55}$ although the justification for extending the indications for this potentially toxic immunosuppressive agent beyond those of organ transplantation remains less than compelling. ${ }^{56}$ These papers only offer interesting pointers to the future. No evidence exists to support the use of either UDCA or cyclosporin outside of clinical trials.

Hoofnagle has emphasized that the treatment of chronic hepatitis B remains experimental. ${ }^{57}$ Interferon given for up to 6 months at doses of 5-10 million units $/ \mathrm{m}^{2}$ per day or thrice weekly can lead to remission in $40 \%$ of recipients. However, relapse rates are high and combination therapy with other antiviral agents may be necessary. Prednisolone withdrawal before interferon may be beneficial and novel anti-hepatitis B DNA treatments may soon be the subject of clinical evaluation. ${ }^{58}$

Much the same conclusion can be drawn from the trials in patients with chronic hepatitis C. Liver enzymes are normalized in $50 \%$ of patients who receive $2-3$ million units interferon 3 times weekly for 6 months..$^{59}$ Of the responders, $50 \%$ relapse within a further 6 months. Combination therapy with other anti-viral agents such as ribavirin ${ }^{60}$ may improve response.

\section{Neuropharmacology}

In no other area of therapeutics has the contribution of basic laboratory research to clinical medicine made such a powerful impact as in neuropharmacology. Animal paradigms of receptor function have allowed screening of literally thousands of substances by iontophoresis. This technique has enabled pharmacologists to pursue structure-activity research to identify a range of agonists and antagonists to neurotransmitter receptors, which could then be evaluated in whole animal toxicity studies. The fruits of this research have become apparent over the past $2-3$ years with exciting advances that take the clinician beyond crude, relatively non-specific agents. Many of these advances depend on an understanding of serotonin receptor pharmacology (Table I).

\section{Serotonin systems}

(i) Sumatriptan Migraine is a common disorder, especially in females, and may affect $10-20 \%$ of the population. Although in some patients migraine may occur frequently and cause considerable distress, it has, in the past, not been taken seriously by doctors, not been clearly defined, and theories about its aetiology have been conflicting and confusing. ${ }^{61}$ During recent years progress has been made in defining the basic neuropharmacological abnormalities and this has led to the possibility of both a more rational and a more effective form of treatment.

Debate has persisted over whether migraine is a vascular disorder that causes neurological sequelae or vice versa. ${ }^{61}$ This controversy has not been finally resolved. However, it is accepted that changes in the concentration of 5-hydroxytryptamine (5-HT; serotonin) are responsible for the dilatation of extracerebral arteries and arteriovenous anastomoses, which occur during the attack.$^{61-64}$ This hypothesis is based on the following observations.

1. Serum 5-HT concentrations increase during the prodromal (aura) phase of a migraine attack and decrease to subnormal concentrations in the headache phase. ${ }^{61}$

2. Migraine attacks may be precipitated in susceptible individuals by reserpine which depletes body 5-HT. ${ }^{62}$

3. Migraine attacks may be relieved by intravenous serotonin ${ }^{63}$ and by specific $5-\mathrm{HT}_{1}$ agonists $^{64}$ together with other agents with similar actions. ${ }^{65,66}$

4. Tissues and organs involved in the migraine attack - brain, blood vessels, gut, and platelets - contain 5-HT that, combined with platelet 5-HT content, falls during a migraine episode. ${ }^{67,68}$

These and other pieces of evidence convincingly linked 5-HT with migraine. However, our understanding of precise mechanisms remained incomplete. A recently reported study ${ }^{69}$ has specifically 
Table I Serotonin receptor systems

\begin{tabular}{|c|c|c|c|c|c|}
\hline Receptor & & Function & Agonists & $\begin{array}{c}\text { Partial } \\
\text { agonists }\end{array}$ & Antagonists \\
\hline \multirow[t]{4}{*}{$5-\mathrm{HT}_{1}$} & A & $\begin{array}{l}\text { Inhibits } 5 \text {-HT neurones; } \\
\text { induces protective response } \\
\text { to anxiety }\end{array}$ & - & Buspirone & Pindolol \\
\hline & B & Inhibits 5-HT release & - & - & - \\
\hline & $\mathrm{C}$ & Induces slow wave sleep & - & - & Ritanserin \\
\hline & D & Inhibits $5-\mathrm{HT}$ release & Sumatriptan & - & Methysergide \\
\hline $5-\mathrm{HT}_{2}$ & & Induces slow wave sleep & - & - & $\begin{array}{l}\text { Ritanserin } \\
\text { Ketanserin } \\
\text { Mianserin } \\
\text { Risperidone }\end{array}$ \\
\hline $5-\mathrm{HT}_{3}$ & & $\begin{array}{l}\text { Involved in regulation of } \\
\text { emesis and neuro- } \\
\text { transmitter release }\end{array}$ & - & - & Ondansetron \\
\hline $5-\mathrm{HT}_{4}$ & - & - & - & - & - \\
\hline
\end{tabular}

addressed the problem of defining the vascular changes associated with an attack of migraine. By measuring regional cerebral blood flow and blood velocity in the middle cerebral artery it was possible to calculate the changes in the middle cerebral artery diameter. During an attack of migraine, changes occur on the affected side. The blood velocity decreases, the vessel diameter increases by about $20 \%$, and the overall regional blood flow remains relatively constant. Since 5-HT exerts a vasoconstrictor action on large arteries and veins through arteriolar dilatation, ${ }^{70}$ sumatriptan, a 5 - $\mathrm{HT}_{1}$-like receptor agonist ${ }^{71,72}$ was a logical treatment.

The impetus, interest, and research in 5-HT receptors, together with the potential for a major therapeutic advance, have increased our knowledge of this subject. ${ }^{73}$ There are several 5-HT receptor subtypes and sumatriptan acts predominantly on 5-HT $\mathrm{T}_{1 \mathrm{~A}}$ and 5-HT $\mathrm{HD}_{1 \mathrm{D}}$ (Table I). Sumatriptan has also proved effective ${ }^{64,71}$ despite its inability to cross the blood - brain barrier. ${ }^{74}$ Other vasoconstrictors such as ergotamine and noradrenaline ${ }^{75,76}$ are also effective but are less selective in their actions.

The basic pharmacology, pharmacokinetics and pharmacodynamics of sumatriptan have been described ${ }^{77}$ Reports on its efficacy and safety are also emerging. A recent report on about 1,000 patients with acute migraine ( 734 given subcutaneous sumatriptan and 370 given placebo) treated in the United States showed striking efficacy with pain reduction in $70 \%$ with sumatriptan vs $22 \%$ with placebo. $^{78}$

Moreover, in a large study ${ }^{79}$ involving 639 patients, $6 \mathrm{mg}$ sumatriptan given subcutaneously was 'highly effective' in migraine attacks and was well tolerated. In a smaller study of patients with cluster headaches, ${ }^{80}$ sumatriptan was also shown to be effective with acceptable tolerability. There are good grounds for believing that $5-\mathrm{HT}_{1}$ blockers will greatly help patients with migraine.

(ii) Ondansetron Cancer chemotherapy has had a considerable impact on the progress of patients with some malignant disorders. Unfortunately many of the regimens used, especially those cor $\mathbb{D}$ taining cisplatin, cause nausea and vomiting, whio $\vec{\varphi}$ is frequently regarded as the worst aspect treatment,${ }^{81}$ and may prevent patients from takin potentially effective therapy. For many years efforts to overcome this difficulty had not proved very effective. The recent appreciation of the role of $5-\mathrm{HT}$, specifically the involvement of $5-\mathrm{HT}_{3}$ receptors, has led to the development of 5- $\mathrm{HT}_{3}$ antagonists. ${ }^{82}$ Ondansetron is a newly available $5-\mathrm{HT}_{3}$ antagonist ${ }^{83,84}$ designed for controlling severe chemotherapy-induced nausea and vomiting.

Drug-induced vomiting results from actions coordinated by the vomiting centre in the lateral reticular formation. Adverse influences from various organs and tissues, such as the stomach, cerebral cortex, and the vestibular nuclei may activate the vomiting centre. In the case of drugs and other metabolic or chemical causes of vomiting the 'message' is transmitted through the chemoreceptor trigger zone (CTZ), which is situated in the area postrema, close to the vomiting centre. Several neurotransmitters, including acetylcholine, dopa- N mine, histamine, noradrenaline, adrenaline, and 5-HT have been found in the area postrema and the neighbouring nucleus of the tractus solitarius. $\omega$ Modifying their actions by, for instance, anticholinergic drugs and antihistamines, may reduce motion sickness, and antidopaminergic agents can relieve nausea and vomiting provoked by disorders that effect the CTZ.

Metoclopramide has been accepted as an effec- 
tive antiemetic ${ }^{85}$ acting as a dopamine antagonist, but has only a modest impact on cisplatin-induced vomiting. ${ }^{86}$ However, when larger doses of metoclopramide are given it is more effective ${ }^{87}$ and this is attributed to its action on $5-\mathrm{HT}_{3}$ receptors near the vagal nerve endings ${ }^{88}$ and in the area postrema. ${ }^{89,90}$ These observations led logically to the idea of developing an agent that would act specifically as an antagonist at 5- $\mathrm{HT}_{3}$ sites. Ondansetron has been the first drug of this sort to be marketed. Other drugs with similar modes of action are moving through the late phases of development so that doctors will not only have a more effective treatment for radiotherapy and chemotherapy-induced vomiting but a choice of preparations.

Ondansetron has been shown to be more effective than metoclopramide in reducing emesis after high-dose radiotherapy. ${ }^{83}$ This multi-centre, randomized, double-blind trial in 82 patients showed a response rate of $97 \%$ in the ondansetron group and $45 \%$ with metoclopramide. Total-body irradiation presents a special difficulty, but open studies with ondansetron and granisetron have produced complete responses in about two thirds of patients. ${ }^{82}$

In studies on patients taking less emetogenic (non-cisplatin containing) regimens, granisetron $(40 \mu \mathrm{g} / \mathrm{kg}$ intravenously (i.v.) followed by two further doses in the first $24 \mathrm{~h}$ ) has been shown to be more effective than a combination of chlorpromazine and dexamethasone. The complete response rates were $70 \%$ and $49 \% .{ }^{91}$ Three double-blind studies comparing ondansetron (i.v. or oral loading dose followed by $8 \mathrm{mg}$ orally 3 times daily) with metoclopromide (60-80 mg i.v. followed by $20 \mathrm{mg}$ orally 3 times daily) have been reviewed in a meta-analysis. ${ }^{92}$ Ondansetron is clearly and significantly more effective. Furthermore the superiority of $5-\mathrm{HT}_{3}$ blockade in patients given cisplatincontaining regimens has also been shown..$^{93,94}$ In this situation infusions of ondansetron (loading dose $8 \mathrm{mg}$ iv followed by $1 \mathrm{mg} / \mathrm{h}$ for $24 \mathrm{~h}$ ) has been compared with high-dose metoclopramide $(3 \mathrm{mg} /$ $\mathrm{kg}$ iv loading dose followed by $0.5 \mathrm{mg} / \mathrm{kg} / \mathrm{h}$ for $8 \mathrm{~h})$. Combining these data from both studies there were no emetic episodes in $44 \%$ on ondansetron compared with $17 \%$ on metoclopramide. ${ }^{84}$ In a double-blind comparison, granisetron has also been shown to be effective, producing results comparable with those of a combination of metoclopramide, dexamethasone, and diphenhydramine. ${ }^{82}$ When dexamethasone is added to a $5-\mathrm{HT}_{3}$ antagonist the antiemetic effect is enhanced.

5- $\mathrm{HT}_{3}$ antagonists appear to be fairly well tolerated. Mild headache and constipation may be caused, but fortunately serious adverse effects on central nervous system function are not a problem. Unfortunately, cost is more likely to be the factor that will limit the use of $5-\mathrm{HT}_{3}$ antagonists to those patients in greatest need. (iii) Buspirone This azapirone is the first example of a new class of drugs with $5-\mathrm{HT}_{1 \mathrm{~A}}$ partial agonist activity. Buspirone acts as an anxiolytic without sedative, muscle relaxant, and anticonvulsant effects. ${ }^{95}$ Buspirone takes several weeks to exert its therapeutic effect and benzodiazepine withdrawal should be completed slowly. This drug's primary indications are generalized anxiety disorder and chronic anxiety states; it is safe, does not lead to dependency, and does not potentiate central nervous system depression caused by alcohol. Buspirone's efficacy in the community when compared with benzodiazepines has been confirmed. ${ }^{96}$

A synergistic effect with fluoxetine in the treatment of obsessive-compulsive disorders has been reported $^{97}$ and buspirone may have equal efficacy with clomipramine. ${ }^{97}$ Buspirone may also be beneficial for patients with an anxiety component within the overall context of a depressive disorder; placebo-controlled studies confirm an advantage in patients receiving buspirone. ${ }^{98-101}$ Review of these trials suggests an instance of dual publication of data. ${ }^{100,101}$

Side effects involve dizziness, light-headedness and headache. Co-administration with monoamine oxidase inhibitors may lead to hypertension and buspirone may increase circulating plasma concentrations of haloperidol. Other azapirones under investigation include ipsapirone, gepirone, and tandospirone.

\section{Psychotropic agents}

(i) Neuroses Although buspirone may offer a new therapeutic option for anxiety disorders, the major difficulty for any new drug treatment remains the chronicity of the condition.

Obsessive-compulsive disorder is diagnosed when ordinary obsessional thoughts and compulsive actions interfere with an individual's functioning. This condition is chronic and has a poor prognosis. Clomipramine has proven efficacy as a 5-HT-reuptake inhibitor, but fluoxetine - a selective serotonin reuptake inhibitor - in high doses is a valuable alternative. ${ }^{102}$

Panic attacks form a distinct category within classifications of anxiety disorders. These attacks are characterized by sudden feelings of terror associated with autonomic symptoms. Tricyclic antidepressives, ${ }^{103}$ monoamine oxidase inhibitors, and alprazolam are all able to control these episodes to some degree. Clonazepam seems to have equal efficacy compared with alprazolam. ${ }^{104}$ Drug treatment is an evolving process and includes acute, stabilization, maintenance, and discontinuation phases. ${ }^{105}$ Clinical trials rarely report longterm follow-up data, but evidence suggests a greater benefit with longer periods of treatment. Drug withdrawal should probably be completed 
slowly over 3-6 months to minimize the risk of relapse.

Benzodiazepines have been a long-standing treatment for insomnia. Their action depends on binding to a benzodiazepine binding site on the benzodiazepine - GABA - chloride channel. When this channel opens, sedation ensues. A new class of drugs, cyclopyrrolones, also bind to this channel and exert a hypnotic effect. Zopiclone has an efficacy similar to that of temazepam in patients with insomnia. ${ }^{106}$ Moreover, zopiclone does not adversely affect psychomotor function, and this agent causes less daytime anxiety than triazolam. ${ }^{107}$ Lack of data about zopiclone's long-term effects and its high cost remain the major disincentives to the would-be prescriber.

Recent concern about psychomotor disturbances, such as paranoia and memory disturbance, has led to the withdrawal of triazolam in the UK.

(ii) Depression When faced with a depressed patient, three important questions must be asked. First, is the patient suicidal? If so, immediate referral to a psychiatrist is required. Second, is the patient psychotic? If so, then an antipsychotic drug may be needed. Third, is the patient elderly? This should exclude use of agents that have important anticholinergic side effects. A summary of new drugs used in the treatment of depression is shown in Table II.
Lofepramine is structurally similar to imipramine and is a non-specific monoamine reuptake inhibitor. There are few anticholinergic, cardiotoxic, and sedative effects with this drug. Efficacy studies show comparability with imipramine and amitripthyline. ${ }^{108}$ Lofepramine has clear advantages in elderly patients and should be the first-line agent in this age group for non-psychotic depression.

Younger patients with biological symptoms insomnia, loss of both appetite and weight, and decreased libido - require drug therapy and tricyclic antidepressives remain the treatment of choice for such individuals. Any new drug must have proven efficacy both acutely and in the long-term. Selective serotonin reuptake inhibitors (SSRI) are strong competitors for first-line agents in the UK, a position they now hold in the USA. Fluoxetine, a bicyclic antidepressive, was the first SSRI to become available. ${ }^{109}$ Steady-state concentrations are reached after 4-6 weeks of treatment and suicidal ideation has been reported, ${ }^{110-112}$ although cause and effect remain unproven. ${ }^{113}$ Fatal interactions with monoamine oxidase inhibitors have been reported, ${ }^{114}$ and fluoxetine may be arrhythmogenic in elderly patients. ${ }^{115}$

Second-generation SSRIs are now available. Sertraline has a product licence for prophylaxisn against relapse of depression, ${ }^{116}$ and is claimed too be psychoneutral with none of the stimulant pro-

Table II New antidepressive agents

\begin{tabular}{|c|c|c|c|c|}
\hline Drug & Dose & Indications & Side effects & Comments \\
\hline Lofepramine & $\begin{array}{l}140-210 \mathrm{mg} \\
\text { daily }\end{array}$ & $\begin{array}{l}\text { Elderly patients with } \\
\text { mild to moderate } \\
\text { depression }\end{array}$ & $\begin{array}{l}\text { Mild anticholinergic side } \\
\text { effects and reversible } \\
\text { changes in liver } \\
\text { function }\end{array}$ & $\begin{array}{l}\text { A definite advance in } \\
\text { treatment of elderly } \\
\text { depressed patients }\end{array}$ \\
\hline Fluoxetine & $\begin{array}{l}20-80 \mathrm{mg} \\
\text { daily }\end{array}$ & $\begin{array}{l}\text { Mild to moderate } \\
\text { depression and } \\
\text { bipolar disorders }\end{array}$ & $\begin{array}{l}\text { Headache, weight loss, } \\
\text { nausea, vasculitis, } \\
\text { anxiety, insomnia, } \\
\text { suicidal ideation, } \\
\text { transient sexual } \\
\text { dysfunction }\end{array}$ & Likely to become \\
\hline Sertraline & $\begin{array}{l}50-200 \mathrm{mg} \\
\text { daily }\end{array}$ & $\begin{array}{l}\text { Acute and chronic } \\
\text { depression; } \\
\text { prophylaxis against } \\
\text { recurrence }\end{array}$ & $\begin{array}{l}\text { Nausea, diarrhoea, } \\
\text { tremor, dizziness, } \\
\text { sexual dysfunction }\end{array}$ & $\begin{array}{l}\text { first-line agents for } \\
\text { mild to moderate } \\
\text { depression }\end{array}$ \\
\hline Paroxetine & $\begin{array}{l}20-50 \mathrm{mg} \\
\text { daily }\end{array}$ & $\begin{array}{l}\text { Mild to moderate } \\
\text { depression; anxiety } \\
\text { with depression }\end{array}$ & $\begin{array}{l}\text { Nausea, somnolence, } \\
\text { sweating }\end{array}$ & \\
\hline Viloxazine & $\begin{array}{l}300-400 \mathrm{mg} \\
\text { daily }\end{array}$ & $\begin{array}{l}\text { Few, efficacy } \\
\text { unconfirmed }\end{array}$ & Nausea $(25-50 \%)$ & \\
\hline Amoxapine & $\begin{array}{l}100-300 \mathrm{mg} \\
\text { daily }\end{array}$ & Few & $\begin{array}{l}\text { Anticholinergic effects, } \\
\text { convulsions, } \\
\text { hypotension, } \\
\text { hyperprolactinaemia, } \\
\text { neuroleptic-associated } \\
\text { side effects }\end{array}$ & $\begin{array}{l}\text { There are no good } \\
\text { reasons to select these } \\
\text { drugs for use outside } \\
\text { of clinical trials }\end{array}$ \\
\hline
\end{tabular}


perties that have been attributed to fluoxetine. A $24 \mathrm{~h}$ half-life reduces the risk of adverse effects with introduction of monoamine oxidase inhibitors, which can be prescribed 1 week after discontinuing sertraline. Few comparative trials are available. Paroxetine may have greater efficacy than imipramine ${ }^{117}$ and anticholinergic, cardiotoxic and psychomotor side effects are uncommon. ${ }^{116}$ Longterm safety and efficacy studies remain few and far between for these newer agents.

Viloxazine and amoxapine ${ }^{108}$ have little to recommend them. Amoxapine is associated with extrapyramidal side effects, tardive dyskinesia, and neuroleptic malignant-syndrome. Viloxazine may prove to be beneficial in depressed alcoholics. ${ }^{18}$ Again, lack of comparative data precludes clear recommendations about use of these agents. The clinical potential of RIMA (reversible inhibitor of monoamine oxidase A-type) drugs remains uncertain. ${ }^{109}$

(iii) Psychoses Psychosis may refer to a schizophrenic (-like) state or to a severe form of affective disorder, most typically a bipolar (manic-depressive) illness. We shall focus on drugs that may be of value for patients with schizophrenia.

Although the anti-psychotic effects of chlorpromazine were discovered in 1950 , the last 40 years have seen comparatively little progress in drug therapy for schizophrenia. The dopamine hypothesis has remained the central dogma that drives neuroleptic research and non-specific drugs with uncomfortably broad side effect profiles have continued to be developed. Anticholinergic actions, hypotension, seizures, and extrapyramidal effects (parkinsonism, akathisia, acute dystonic reactions and tardive dyskinesias), together with neuroleptic-malignant syndrome, all limit the longterm tolerance to and efficacy of neuroleptic agents.

However, a new era of antipsychotic drug research emerged in the early $1990 \mathrm{~s}$. The edifice of the dopamine hypothesis has been under severe attack $^{119}$ and is now, at least, partly discredited. Newer drugs belong to a poorly defined, but clearly separate, group designated 'atypical' antipsychotics. These drugs often have dopamine-receptor specificity with little sedative action and few extrapyramidal side effects. The two major new drugs to evaluate are clozapine and remoxipride.

(a) Clozapine Clozapine has a wide spectrum of activity and is an antagonist at D1 and D2 receptors and $\alpha_{1}$ and $\alpha_{2}$ receptors, as well as 5-HT, $\mathrm{H}_{1}$-histamine, and muscarinic sites. However, clozapine exerts only weak antagonism at dopamine receptors in the basal ganglia and limbic forebrain and so lacks acute extrapyramidal side effects. Tardive dyskinesia also seems rare. ${ }^{120}$ This dibenzodiazepine is licensed for the treatment of schizophrenia unresponsive to other agents. ${ }^{121}$

The main source of concern about this drug centres around its unusual adverse-reaction profile. The cumulative frequency of agranulocytosis is $1 \%$ at 1 year and this effect may have a genetic basis. ${ }^{122}$ Such a potentially fatal complication can be prevented by weekly white cell counts during the initial 18 weeks of treatment followed by fortnightly assessments thereafter. ${ }^{123}$ Compliance with this protocol is ensured by patient registration with the Clozaril Patient Monitoring Service. Seizures occur in $3-4 \%$ of patients receiving moderate doses of clozapine and are dose-dependent; cardiovascular toxicity may take place with too rapid titration. Only psychiatrists may prescribe clozapine and the monitoring requirements make this drug prohibitively expensive.

(b) Remoxipride Remoxipride is a substituted benzamide that is selective for central, especially extrastriatal, D2 receptors. This new drug has comparative efficacy with haloperidol in the treatment of both positive and negative symptoms of patients with acute and chronic schizophrenia, including those with severe psychosis. A once daily oral preparation is available and peak plasma concentrations are achieved within 1-2 h after intramuscular injection.

Extrapyramidal symptoms and sedative effects are substantially fewer with remoxipride and its efficacy is maintained over 12 months. Cognitive function seems to be improved, whereas haloperidol diminishes intellectual performance. Morever, neuroendocrine responses to single doses of remoxipride are minimal. ${ }^{124}$ Prevention of relapse in chronic schizophrenics remains to be established, but advantages over more traditional neuroleptics seem clear. ${ }^{125}$ Remoxipride seems a real advance in antipsychotic drug therapy.

(c) Miscellaneous therapies $\beta$-Blockers may have the potential to reduce both aggression and anxiety among schizophrenic subjects. ${ }^{126}$ Moreover, propranolol may benefit patients with akathisia. ${ }^{127}$ Risperidone is a dopamine D2 and 5- $\mathrm{HT}_{2}$ antagonist; it improves negative symptoms and has few extrapyramidal effects. ${ }^{128}$ Phase III trials are now in progress. The benefits of the drug again point to the importance of serotonergic systems in psychiatric disorders. Amisulpride has equal efficacy with haloperidol and fewer extrapyramidal actions. ${ }^{129}$

\section{Alzheimer's disease}

The impact of Alzheimer's disease on patients, their relatives, and accompanying medical services is enormous. Large and increasing numbers of patients are affected, and the incentive to find a drug that might prevent or even delay the progress 
of this disorder is great. Not surprisingly, therefore, many institutions and drug companies are striving to find a therapeutic agent, and 12 drugs are currently being reviewed by a special unit in the American Food and Drugs Administration. One, tacrine (tetrahydroaminoacridine), has been reviewed after a positive clinical trial report in the Lancet in April 1991, ${ }^{130}$ but was not approved. ${ }^{131}$

Alzheimer's disease is a disease of unkown aetiology, but evidence points to a deficiency in one of the neurotransmitter systems, notably the cholinergic system. ${ }^{132-134}$ However, neurochemical abnormalities tend to be detected at necropsy and may bear little relation to the situation at the time disease becomes symptomatic. Furthermore, there are several different neurotransmitter deficiencies in Alzheimer's disease ${ }^{135}$ and interest in other systems such as those involving serotonin ${ }^{136}$ indicates that the search for the cause of Alzheimer's disease may still be at an early stage. A cholinergic deficit might offer the potential for corrective therapy as in Parkinson's disease. Since acetylcholine has a short half-life, efforts have been directed towards enhancing cholinergic activity by giving precursors, ${ }^{137,138}$ cholinergic agents, ${ }^{139}$ and anticholinesterases. ${ }^{140,141}$ An alternative would be to use acetylcholine-release promotors. ${ }^{142}$ A group of aminopyridines enhance transmitter release by prolonging depolarization through potassium channel blockade and increasing calcium influx. ${ }^{143}$ Although these compounds have had some effects in experimental models, they have not proved effective clinically. ${ }^{142}$

Meaningful research into new agents for the treatment of Alzheimer's disease requires the following.

1. The disease should be recognizable and diagnosable at a fairly early stage when it is most likely to be reversible, treatable, or controllable.

2. The key abnormalities should be quantifiable and changes should be susceptible to objective monitoring.

3. Any trial should be double-blind and long enough to enable changes in the course of disease to be reversed.

4. The drug should reach the relevant part of the central nervous system, achieve an appropriate tissue concentration, and produce a selective effect without distorting the whole of the parasympathetic nervous system or some other neurotransmitter system.

5. The impact of the drug should be on the disease itself and not simply to modify secondary factors such as mood or sleep patterns. Clinical observation suggests that patients who present with dementia may improve or seem to improve in response to having infections cured, Parkinson's disease treated, hypothyroidism corrected, or depression alleviated. Equally they may respond when unnecessary medications such as sedatives are stopped.

6. The drug must be fairly long acting, easy to administer, relatively inexpensive, and well tolerated.

It is of interest that the study on 'Tacrine in Alzheimer's disease' was accepted for publication in the Lancet but did not convince the Food and Drugs Administration. ${ }^{131}$ Drug trials in Alzheimer's disease are now becoming increasingly complicated. In the Lancet paper, care has clearly been taken over clinical trial technique, diagnosis, documentation, monitoring of progress, and determination of drug dose. Sceptics may draw attention to the large number of evaluations that are made and which increase the likelihood of finding a 'significant' $P<0.05$ difference. The duration of treatment was only 13 weeks. Although patients with Parkinson's disease may respond rapidly, and therefore it is possible to produce symptomatic improvements in neurological disorders with neurotransmitter deficiencies, a fundamental impact on Alzheimer's disease seems likely to require prolonged therapy. Finally, 24 of $89(27 \%)$ patients were withdrawn (12 for abnormalities of liver function tests) and $72 \%$ had side effects. These figures illustrate the difficulties in obtaining long-o term follow-up data. The effects on liver function tests have been evaluated further ${ }^{144}$ and it seems that in many cases they return to normal spontaneously and do not recur.

It was entirely predictable that the progress toward a suitable treatment for Alzheimer's disease would be difficult. Many doctors take a nihilistic approach and others may be overenthusiastic about new developments. The tacrine paper must be seen as both encouraging and a milestone on the road to better clinical trials. The value of this compound remains to be established. However, it is probably a disservice to patients with Alzheimer's disease and those who manage them to draw conclusions from trials with too few patients. ${ }^{145}$ or from studies in which treatment was only given for 3 weeks ${ }^{146}$ before concluding that 'THA has no clinically important benefits'.

There are a large number of possible options ${ }^{147}$ one or more of which may yield potential benefits. Intramuscular desferrioxamine is one such avenue that requires further investigation. ${ }^{148}$ For the nonspecialist, there will be a need to combine an understanding of the difficulties that face the investigator with the requirement for clinical trials that are well designed with clearly defined patient groups, objective, relevant assessments, and adequate treatment periods. ${ }^{149}$ Inadequate trials will lead to a situation in which deluded doctors are treating demented patients. 


\section{Acknowledgement}

We wish to thank Mrs Jean Bourne for her patient and careful preparation of this manuscript.

\section{References}

\section{Cardiovascular pharmacology}

1. Rankin, A.C. \& McGovern, B.A. Adenosine or verapamil for the acute treatment of supraventricular tachycardia? Ann Intern Med 1991, 114: 513-515.

2. Griffiths, M.J., Linker, N.J., Garratt, C.J., Ward, D.E. \& Camm, A.J. Relative efficacy and safety of intravenous drugs for termination of sustained ventricular tachycardia. Lancet 1990, 336: 670-673.

3. The CAST Investigators. Preliminary report: effect of encainide and flecainide on mortality in a randomised trial of arrhythmia suppression after myocardial infarction. $N$ Engl J Med 1989, 321: 406-412.

4. Echt, D.S., Liebson, D.R., Mitchell, L.B. et al. Mortality and morbidity in patients receiving encainide, flecainide, or placebo. N Engl J Med 1991, 324: 781-788.

5. Editorial. Propafenone: an antiarrhythmic come in from the cold. Lancet 1989, ii: 1490-1491.

6. Hernandez, M., Reder, R.F., Marinchak, R.A., Rials, S.J. \& Kowey, P.R. Propafenone for malignant ventricular arrhythmia: an analysis of the literature. Am Heart J 1991, 121: $1178-1184$.

7. Ryden, L., Ariniego, R., Arnman, K. et al. A double blind trial of metoprolol in acute myocardial infarction. Effect on ventricular arrhythmias. $N$ Engl J Med 1983, 308: 614-618.

8. Murray, D.S., Murray, R.G. \& Littler, W.A. The effects of metoprolol given early in acute myocardial infarction on ventricular arrhythmias. Eur Heart J 1986, 7: 217-222.

9. Friedman, L.M., Brington, R.P., Caponie, R.J., Furberg, C.D., Goldstein, S. \& Lichstein, E. Effect of propranolol in patients with myocardial infarction and ventricular arrhythmias. J Am Coll Cardiol 1986, 7: 1-5.

10. The Norwegian Multicentre Study Group. Timolol-induced reduction in mortality and reinfarction in patients surviving acute myocardial infarction. $N$ Engl $J$ Med 1981, 304: 801-807.

11. Parker, G.W., Michael, L.H., Hartley, C.J., Skinner, J.E. \& Entman, M.L. Central $\beta$-adrenergic mechanisms may modulate ischaemic ventricular fibrillation in pigs. Circ Res 1990, 66: 259-270

12. Dellsperger, K.C., Martins, J.B., Clothier, J.L. \& Marcus, M.L. Incidence of sudden cardiac death associated with coronary artery occlusion in dogs with hypertension and left ventricular hypertrophy is reduced by chronic $\beta$-adrenergic blockade. Circulation 1990, 82: 941-950.

13. Ablad, B., Bjuro, T., Bjorkman, J.A., Edstrom, T. \& Olsson, G. Role of central nervous beta-adrenoceptors in the prevention of ventricular fibrillation through augmentation of cadiac vagal tone. J Am Coll Cardiol 1991,17: 165A.

14. Mann, H.J., Moricizine: a new class I antiarrhythmic. Clin Pharm 1990, 9: 842-852.

15. Burkart, F., Pfisterer, M., Kiowski, W., Follath, F., Burck hardt, D. \& Jordi, H. Effect of antiarrhythmic therapy on mortality in survivors of myocardial infarction with asymptomatic complex ventricular arrhythmias. J Am Coll Cardiol 1990, 16: $1711-1718$

\section{Gastroenterology}

16. Hogan, W.J. Gastroesophageal reflux disease: an update on management. J. Clin Gastroenterol 1990, 12 (Suppl 2): S21-S28.

17. Dehn, T.C.B., Shepherd, H.A., Colin-Jones, D., Kettlewell, M.G.W. \& Carroll, N.J.H. Double-blind comparison of omeprazole ( $40 \mathrm{mg}$ od) versus cimetidine $(400 \mathrm{mg} \mathrm{qd}$ ) in the treatment of symptomatic erosive oesophagitis, assessed endoscopically, histologically and by $24 \mathrm{~h} \mathrm{pH}$ monitoring. Gut 1990, 31: 509-513.

18. Bate, C.M., Keeling, P.W.N., O'Morain, C. et al. Comparison of omeprazole and cimetidine in reflux oesophagitis: symptomatic, endoscopic, and histological evaluations. Gut 1990, 31: 968-972.

19. Koop, H., Hutz, J., Pommer, G., Klein, M. \& Arnold, R. Prospective evaluation of omeprazole treatment in reflux oesophagitis refractory to $\mathrm{H}_{2}$-receptor antagonists. Aliment Pharmacol Therap 1990, 4: 593-599.

20. Committee on Safety of Medicines. Diarrhoea, skin reactions and headache following omeprazole therapy. Current Problems 1991, June: 3.

21. Editorial. Omeprazole and genotoxicity. Lancet 1990, 335: 386.

22. Galmiche, J.P., Fraitag, B., Filoche, B. et al. Double-blind comparison of cisapride and cimetidine in treatment of reflex oesophagitis. Dig Dis Sci 1990, 35: 649-655.

23. Anonymous. Cisapride - more selective than metoclopramide. Drug Therap Bull 1990, 28: 89-90.

24. Anonymous. Algitec: an illogical combination? Drug Therap Bull 1990, 28: 76.

25. Cooperative Oesophageal Group. Combination of cimetidine and alginic acid: an improvement in the treatment of oesophageal reflux disease. Gut 1991, 32: 819-822.

26. Lee, F.I., Hardman, M. \& Jaderberg, M.E. Maintenance treatment of duodenal ulceration: ranitidine $300 \mathrm{mg}$ at night is better than $150 \mathrm{mg}$ in cigarette smokers. Gut 1991, 32: $151-153$.

27. Bardhan, K.D., Naesdal, J., Porro, G.B. et al. Treatment of refractory peptic ulcer with omeprazole or continued $\mathrm{H}_{2}$ receptor antagonists: a controlled clinical trial. Gut 1991, 32: 435-438.

28. McFarland, R.J., Bateson, M.C., Green, J.R.B. et al. Omeprazole provides quicker symptom relief and duodenal ulcer healing than ranitidine. Gastroenterology 1990, 98: 278-283.

29. Glise, H., Martinson, J., Solhaug, J.H. et al. Two and four weeks' treatment for duodenal ulcer: symptom relief and clinical remission comparing omeprazole and ranitidine. Scand J Gastroenterol 199.1, 26: 137-145.

30. Lauritsen, K., Andersen, B.N., Laursen, L.S. et al. Omeprazole $20 \mathrm{mg}$ three days a week and $10 \mathrm{mg}$ daily in prevention of duodenal ulcer relapse. Gastroenterology 1991, 100: 663-669.

31. Rauws, E.A.J. \& Tytgat, G.N.J. Cure of duodenal ulcer associated with eradication of Helicobacter pylori. Lancet 1990, 335: $1233-1235$.

32. Biasco, G., Miglioli, M., Barbara, L., Covinaldesi, R. \& Di Febo, G. Omeprazole, Helicobacter pylori, gastritis, and duodenal ulcer. Lancet 1991, 337: 1403.

33. Arns, P.A. Misoprostol. Am J Med Sci 1991, 301: 133-137.

34. Knoll-Jones, R., Drummond, M., Kohli, H. \& Davies, L. Economic evaluation of gastric ulcer prophylaxis in patients with arthritis receiving NSAIDS. Postgrad Med J 1990, 66: 639-646.

35. McCarthy, D.M. NSAID-induced gastrointestinal damage. J Clin Gastroenterol 1990, 12 (Suppl 2): S13-S20.

36. Fonseca, W., Alencar, A.J.C., Mota, F.S.B. \& Coelho, H.L.L. Misoprostol and congenital malformations. Lancet 1991, 338: 56

37. Camilleri, M. \& Fealey, R.D. Idiopathic autonomic denervation in eight patients presenting with functional gastrointestinal disease: a causal association? Dig Dis Sci 1990, 35: 609-616.

38. Kellow, J.E., Gill, R.C. \& Wingate, D.L. Prolonged ambulant recordings of small bowel motility demonstrate abnormalities in the irritable bowel syndrome. Gastroenterology 1990, 98: $1208-1218$.

39. Janssens, J., Peeters, T.L., Vantrappen, G. et al. Improvement of gastric emptying in diabetic gastroparesis by erythromycin: preliminary studies. $N$ Engl J Med 1990, 322: $1028-1031$ 
40. Mozwecz, H., Pavel, D., Pitrak, D., Orellana, P., Schlesinger, P.K. \& Layden, T.J. Erythromycin stearate as prokinetic agent in postvagotomy gastroparesis. Dig Dis Sci 1990, 35: 902-905.

41. Depoortere, I., Peeters, T.L. \& Vantrappen, G. Development of motilin receptors and of motilin and erythromycin induced contractility in rabbits. Gastroenterology 1990, 99: 652-658.

42. O'Donnell, L.J.D., Watson, A.J.M., Cameron, D. \& Farthing, M.J.G. Effect of octreotide on mouth-to-caecum transit time in healthy subjects and in the irritable bowel syndrome. Aliment Pharmacol Therap 1990, 4: 177-181.

43. Staumont, G., Fioramonti, S., Frexinos, J. \& Bueno, L. Oral prostaglandin $\mathrm{E}$ analogues induce intestinal MMCs after a meal in dogs. Gastroenterology 1990, 98: 888-893.

44. Chapman, N.D., Grillage, M.G., Mazumder, R. \& Atkinson, S.N. A comparison of mebeverine with high-fibre dietary advice and mebeverine plus ispaghula in the treatment of irritable bowel syndrome. Br J Clin Pract 1990, 44: 461-466.

45. Van Outryve, M., Milo, R., Toussaint, J. \& Van Eeghem, P. Prokinetic treatment of constipation-predominant irritable bowel syndrome: placebo-controlled study of cisapride. $J$ Clin Gastroenterol 1991, 13: 49-57.

46. Kaski, M.C., Peters, A.M., Lavender, J.P. \& Hodgson, H.J.F. Fluticasone propionate in Crohn's disease. Gut 1991, 32: $657-661$.

47. Hayllar, J. \& Bjarnason, I. Sulphasalazine in ulcerative colitis: in memoriam? Gut 1991, 32: 462-463.

48. Kendall, M.J. \& Horton, R.C. Clinical pharmacology and therapeutics. Postgrad Med J 1990, 66: 166-185.

49. Laursen, L.S., Stokholm, M., Bukhave, K., Rask-Madsen, J. \& Lauritsen, K. Disposition of 5-aminosalicyclic acid by olsalazine and three mesalazine preparations in patients with ulcerative colitis. Gut 1990, 31: 1271-1276.

50. Courtney, M.G., Nunes, D.P., Bergin, C.F. et al. A prospective trial of mesalazine vs olsalazine in the maintenance treatment of ulcerative colitis. World Congress of Gastroenterology, Sydney, Australia, August 1990: 727.

51. Teres Plands, R. \& Panes, J. et al. Vasopressin/nitroglycerin infusion vs esophageal tamponade in the treatment of acute variceal bleeding. Hepatology 1990, 11: 964-968.

52. Hayes, P.C., Davis, J.M., Lewis, J.A. \& Bouchier, I.A.D. Meta-analysis of value of propanolol in prevention of variceal haemorrhage. Lancet 1990, 336: 153-156.

53. Crosignani, A., Battezzati, P.M., Setchell, K.D. et al. Effects of ursodeoxycholic acid on serum liver enzymes and bile acid metabolism in chronic active hepatitis. Hepatology 1991, 13: $339-344$.

54. Leuschner, J., Fischer, H., Kurtz, W. et al. Ursodeoxycholic acid in primary biliary cirrhosis: results of a controlled double-blind trial. Gastroenterology 1989, 97: 1268-1274.

55. Wiesner, R.H., Ludwig, J., Lindor, K.D. et al. A controlled trial of cyclosporin in the treatment of primary biliary cirrhosis. N Engl J Med 1990, 332: 1419-1424.

56. Horton, R. Cyclosporin. Lancet 1991, 337: 1338.

57. Hoofnagle, J.H. Alpha-interferon therapy of chronic hepatitis B: current status and recommendations. $J$ Hepatol 1990, 11 (Suppl 1): S100-S107.

58. Blum, H.E., Galun, E., Weizsacker, F.V. \& Wands, J.R. Inhibition of hepatitis B virus by antisense oligodeoxynucleotides. Lancet 1991, 337: 1230.

59. Davis, G.L., Balart, L.A., Schiff, E.R. et al. Treatment of chronic hepatitis $\mathbf{C}$ with recombinant alpha-interferon. $J$ Hepatol 1990, 11 (Suppl 1): S31-S35.

60. Reichard, O., Andersson, J., Schvarcz, R. \& Weiland, O. Ribavirin treatment for chronic hepatitis C. Lancet 1991, 337: $1058-1061$.

\section{Neuropharmacology}

61. Edmeads, J. What is migraine? Controversy and stalemate in migraine pathophysiology. J Neurol 1991, 238: S2-S5.
62. Curzon, G., Barie, M. \& Wilkinson, M.P. Relationship between headache and amine changes after administration of reserpine to migrainous patients. J Neurol Neurosurg Psychiat 1969, 32: 555-561.

63. Kimball, R.W., Friedman, A.P. \& Vallejo, E. Effect of serotonin in migraine patients. Neurology 1960, 10: 107-111.

64. Ferrari, M., Bayliss, E.M., Ludlow, S. \& Pilgrim, A.J Subcutaneous GR43175 in the treatment of acute migraine: an international study. Cephalalgia 1989, 9 (Suppl 10): S348

65. Humphrey, P.P.A., Feniuk, W. \& Perren, M.J. Antimigraine drugs in development: advances in serotonin receptor pharmacology. Headache 1990, 30: 12-16.

66. Sayena, P.R. \& DenBoer, M.O. Pharmacology of antimigraine drugs. $J$ Neurol 1991, 238: S28-S35

67. Curran, D.A., Hunterberger, H. \& Lance, J.W. Total plasma serotonin, 5 hydroxyindoleacetic acid and p-hydroxy-,-methoxy mandelic acid excretion in normal and migrainous subjects. Brain 1965, 88: 997-1007.

68. Fozard, J.R. Serotonin, migraine and platelets. Prog Phar macol 1982, 4: 136-146.

69. Friberg, L., Olesen, J., Iversen, H.K. \& Sperling, B. Migraine pain associated with middle cerebral artery dilatation: reversal by sumatriptan. Lancet 1991, 338: 13-17.

70. Declerek, F. \& Reneman, R.S. Platelet derived serotonin and abnormal tissue perfusion. In: VanLeutte, P.M. (ed.) Serotonin and the Cardiovascular System. Raven Press, New York, 1985, pp. 155-164.

71. Doenicke, A., Brand, J. \& Perren, V.L. Possible benefits of GR43175C, a novel $5 \mathrm{HT}_{1}$ agonist for the acute treatment of severe migraine. Lancet 1988, i: 1309-1311.

72. Fenuik, W., Humphrey, P.P.A. \& Perren, M.L. The selective carotid arterial vasoconstrictor action of GR43175 in anaesthetised dogs. Br J Pharmacol 1989, 96: 83-90.

73. Raskin, N.H. Serotonin receptors and headache. $N$ Engl 0 Med 1991, 325: 353-354.

74. Humphrey, P.P.A., Feniuk, W., Perren, M.J., Beresfords J.M., Skingle, M. \& Whalley, E.T. Serotonin and migraine Ann NY Acad Sci 1990, 600: 587-598.

75. Humphrey, P.P.A. 5 Hydroxytryptamine and the pathophysiology of migraine. J Neurol 1991, 238: 538-544.

76. Ostfield, A.M. \& Wolfe, H.G. Studies on headache arterenol (norepireptnine) and vascular headache of the migraine type. Arch Neurol Psychiat 1955, 74: 131-136.

77. Fowler, P.A., Lacey, L.F., Thomas, M., Keene, O.N., Tanner, R.J.W. \& Baber, N.S. The clinical pharmacology, pharmacokinetics and metabolism of sumatriptin. Eur Neurol 1991, 31: 291-294.

78. Cady, R.K., Wendt, J.K., Kirchner, J.R., Sargent, J.D., Rothrock, J.F. \& Skaggs, H. Treatment of acute migraine with sumatripten. JAMA 1991, 265: 2831-2835.

79. The Subcutaneous Sumatriptan International Study Group Treatment of migraine attacks with sumatriptan. $N$ Engl Med 1991, 325: 316-321.

80. The Sumatriptan Cluster Headache Study Group. The treament of acute cluster headache with sumatriptan. $N$ Eng J Med 1991, 325: 322-326.

81. Coates, A., Abraham, S., Kaye, B.B. et al. On the receiving end - patient perception of side effects of cancer chemotherapy. Eur J Cancer Clin Oncol 1988, 19: 203-208.

82. Freeman, A.J. \& Cullen, M.H. Advances in the management of cytotoxic drug-induced nausea and vomiting. J Clin Pharm Therap 1991 (in press).

83. Priestman, T.J. Clinical studies with ondansetron in the control of radiation-induced emesis. Eur $J$ Cancer Clin Oncol 1989, 25 (Suppl 1): S29-S33.

84. Marty, M. Ondansetron in the prophylaxis of acute cisplatin-induced nausea and vomiting. Eur J Cancer Clin Oncol 1989, 25 (Suppl 1):S41-S45.

85. Triozzi, P.L. \& Laszlo, J. Optimum management of nausea and vomiting in cancer chemotherapy. Drugs 1989, 34: 136-149. 
86. Moertel, C.G., Reilemeier, R.J. \& Gage, R.P. Controlled clinical studies of orally administered antiemetic drugs. Gastroenterology 1969, 57: 262-268.

87. Gralla, R.J., Tiri, L.M. \& Pisko, S.E. et al. Antiemetic efficacy of high dose metoclopromide: randomised trials with placebo and prochlorperazine in patients with chemotherapy-induced nausea and vomiting. $N$ Engl $J$ Med 1981, 30: 905-909.

88. Butler, A., Hill, J.M., Ireland, S.J., Jordan, C.C. \& Tyers, M.D. Pharmacological properties of GR38032F, a novel antagonist at $5 \mathrm{HT}_{3}$ receptors. $\mathrm{Br} J$ Pharmacol 1988, 94: $397-412$.

89. Tyers, M.B., Bunce, K.T. \& Humphrey, P.P.A. Pharmacological and antiemetic properties of ondansetron. Eur $J$ Cancer Clin Oncol 1989, 25 (Suppl 1): S515-S519.

90. Kilpatrick, G.J., Jones, B.J. \& Tyers, M.B. Identification and distribution of $5 \mathrm{HT}_{3}$ receptors in rat brain using radioligand binding. Nature 1987, 330: 746-748.

91. Marty, M. A comparative study of the use of granisetron, a selective $5 \mathrm{HT}_{3}$ antagonist versus a standard antiemetic regimen of clorpromazine plus dexamethasone in the treatment of cytostatic induced emesis. Eur J Cancer 1990, 26 (Suppl 1): S28-S32.

92. Schmoll, H.J. The role of ondansetron in the treatment of emesis induced by non-cisplatin containing chemotherapy regimens. Eur J Cancer Clin Oncol 1989, 25 (Suppl 1): S35-S39.

93. Marty, M., Pouillart, P., Scholl, S. et al. Comparison of the 5 hydroxytryptamine (serotonin) antagonist ondansetron with high dose metoclopromide in the control of cisplatin induced emesis. $N$ Engl $J$ Med 1990, 322: 816-821.

94. de Mulder, P.H.M., Seynaeve, C., Vermorken, J.B., Van Leissum, P., Mols-Jerdevic, S., Lane-Allman, E., Beranek, P. \& Verweu, J. Ondansetron (GR38032F) versus high dose metoclopromide in the prophylaxis of acute and delayed cisplatin induced nausea and vomiting. Ann Intern Med 1990, 113: 834-840.

95. Rickels, K. Buspirone in clinical practice. J Clin Psychiat 1990, 51 (Suppl): S51-S54.

96. Strand, M., Hetta, J., Rosen, A. et al. A double-blind, controlled trial in primary care patients with generalised anxiety: a comparison between buspirone and oxazepam. $J$ Clin Psychiat 1990, 51 (Suppl): S40-S45.

97. Jenike, M.A., Baer, L. \& Buttolph, L. Buspirone augmentation of fluoxetine in patients with obsessive-compulsive disorder. J Clin Psychiat 1991, 52: 13-14.

98. Pato, M.T., Pigott, T.A., Hill, J.L., Grover, G.N., Bernstein, S. \& Murphy, D.L. Controlled comparison of buspirone and clomipramine in obsessive-compulsive disorder. $\mathrm{Am} J$ Psychiat 1991, 148: 129-139.

99. Fabre, L.F. Buspirone in the management of major depression: a placebo-controlled comparison. J Clin Psychiat 1990, 51 (Suppl): 55-61.

100. Rickels, K., Amsterdam, J., Clary, C. et al. Buspirone in depressed outpatients: a controlled study. Psychopharmacol Bull 1990, 26: 163-167.

101. Rickels, K., Amsterdam, J.D., Clary, C., Pyzzroli, G. \& Schweizer, E. Buspirone in major depression: a controlled study. J Clin Psychiat 1991, 52: 34-38.

\section{Neuroses}

102. Pigott, T.A., Pato, M.T., Bernstein, S.E. et al. Controlled comparisons of clomipramine and fluoxetine in the treatment of obsessive-compulsive disorder. Arch Gen Psychiat 1990, 47: 926-932.

103. Deltito, J.A., Argule, N. \& Klerman, G.L. Patients with panic disorder unaccompanied by depression improved with alprazolam and imipramine treatment. J Clin Psychiat 1991, 52: $121-127$.

104. Tesar, G.E., Rosenbaum, J.F., Pollock, M.H. et al. Doubleblind placebo-controlled comparison of clonazepam and alprazolam for panic disorder. J Clin Psychiat 1991, 52: $121-127$.
105. Ballenger, J.C. Long-term pharmacologic treatment of panic disorder. J Clin Psychiat 1991, 52 (Suppl): 18-23.

106. Ngen, C.C. \& Hassan, R. A double-blind placebo-controlled trial of zopiclone $7.5 \mathrm{mg}$ and temazepam $20 \mathrm{mg}$ in insomnia. Int Clin Psychopharmacol 1990, 5: 165-171.

107. Fontaine, R., Beaudry, P., Morvan, P.L., Beauclair, L. \& Chouinard, G. Zopiclone and triazolam in insomnia associated with generalised anxiety disorder: a placebocontrolled evaluation of efficacy and daytime anxiety. Int Clin Psychopharmacol 1990, 5: 173-183.

\section{Depression}

108. Anonymous. Update of antidepressants: lofepramine, amoxapine, and viloxazine. Drugs Therap Bull 1990, 28: 82-84.

109. Anonymous. If at first you do succeed. Lancet 1991, 337: $650-651$.

110. Teicher, M.M., Glod, C. \& Cole, J.O. Emergence of intense suicidal preoccupation during fluoxetine treatment. $\mathrm{Am} \mathrm{J}$ Psychiat 1990, 147: 207-210.

111. Dasgupta, K. \& Hoover, C.E. Additional cases of suicidal ideation associated with fluoxetine. Am J Psychiat 1990, 147: 1570-1571.

112. Masand, P., Gupta, S. \& Dewan, M. Suicidal ideation related to fluoxetine treatment. $N$ Engl J Med 1991, 324:420.

113. Fava, M. \& Rosenbaum, J.F. Suicidality and fluoxetine: is there a relationship? J Clin Psychiat 1991, 52: 108-111.

114. Anonymous. Fluoxetine: another new antidepressive. Drugs Therap Bull 1990, 28: 33-34.

115. Buff, D.D., Brenner, R., Kirtane, S.S. \& Gilboe, R. Dysrhythmia associated with fluoxetine treatment in an elderly patient with cardiac disease. J Clin Psychiat 1991, 52: 134-176.

116. Anonymous. Sertraline and paroxetine-new drugs for the treatment of depression. Drugs Therap Bull 1991, 29: 46-47.

117. Feighner, J.P. \& Boyer, W.F. Paroxetine in the treatment of depression: a comparison with imipramine and placebo. Acta Psychiatr Scand 1989, 80 (Suppl 350): 129-139.

118. Altamura, A.C., Mouri, M.C., Girardi, T. \& Panetta, B. Alcoholism and depression: a placebo-controlled study with viloxazine. Int J Clin Pharmacol Res 1990, 10: 293-298.

\section{Psychoses}

119. Moises, H.W., Gelernter, J., Giuffra, L.A. et al. No linkage betwen D2 dopamine receptor gene region and schizophrenia. Arch Gen Psychiat 1991, 48: 643-647.

120. Borison, R.L. \& Diamond, B.I. New advances in psychotherapeutic agents: clozapine. Psychiatr Med 1990, 8: 13-21.

121. Kane, J., Honigfeld, G., Singer, J. et al. Clozapine for the treatment-resistant schizophrenic: a double-blind comparison with chlorpromazine. Arch Gen Psychiat 1988, 45: 789-796.

122. Lieberman, J.A., Yunis, J., Egea, E., Canoso, R.J., Kane, J.M. \& Yunis, E.J. HLA-B38, DR4, DQW3 and clozapineinduced agranulocytosis in jewish patients with schizophrenia. Arch Gen Psychiat 1990, 47: 945-948.

123. Anonymous. Clozapine and loxapine for schizophrenia. Drug Therap Bull 1991, 29: 41-42.

124. von Bahr, C., Wiesel, F.A, Morin, G. et al. Neuroendocrine responses to single oral doses of remoxipride and sulpuride in healthy female and male volunteers. Psychopharmacology 1991, 103: 443-448.

125. Wadworth, A.N. \& Heel, R.C. Remoxipride. Drugs 1990, 40: 863-879.

126. Nutt, D. Specific anatomy, non-specific drugs: the present state of schizophrenia. J Psychopharmacol 1990, 4: 171-175.

127. Fleischhacker, W.W., Roth, S.D. \& Kane, J.M. The pharmacologic treatment of neuroleptic-induced akathisia. J Clin Psychopharmacol 1990, 10: 87-91. 
128. Cuyper, H.D., Claus, A., Bollen, J. et al. Risperidone vs haloperidol in chronic schizophrenia. 17th Congress Collegium Internationale Neuro-Psychopharmacologicum Abstracts 1990, 33.

129. Delcher, A., Schoon, M.L., Oczkowski, B. \& Gaertner, M.J. Amisulpride versus haloperidol in treatment of schizophrenic patients. Pharmacopsychiatry 1990, 23: 125-130.

\section{Alzheimer's disease}

130. Eagger, S.A., Levy, R. \& Sahakian, B.J. Tacrine in Alzheimer's disease. Lancet 1991, 337: 989-992.

131. Anonymous. US refuses approval for tacrine. Lancet 1991, 338: 244.

132. Perry, E.K., Perry, R.H., Blessed, G. \& Tomlinson, B.E. Necropsy evidence of central cholinergic deficits in senile dementia. Lancet 1977, i: 189.

133. Coyle, J.T., Price, D.T. \& Dehony, M.R. Alzheimer's disease: a disorder of cortical cholinergic innervation. Science 1983, 219: 1184-1190.

134. Perry, E.K. The cholinergic hypothesis -10 years on. $\mathrm{Br}$ Med Bull 1986, 42: 63-69.

135. Whalley, L.J. Drug treatment of dementia. Br J Psychiat 1989, 155: 595-611.

136. Cross, A.J. Serotonin in Alzheimer's type dementia and other dementing illnesses. Ann NY Acad Sci 1990, 600: 405-415.

137. Thal, L.J., Rosen, W., Sharpless, N.J. \& Crystal, H. Choline chloride in Alzheimer's disease. Ann Neurol 1981, 10: 580.

138. Etienne, P., Dastoor, D., Gauthier, S., Ludwick, R. \& Collier, B. Alzheimer's disease: lack of effect of lecithin treatment for 3 months. Neurology 1981, 31: 1552-1554.

139. Harbaugh, R.E., Roberts, D.W., Doombs, D.W., Saunders, R.L. \& Reeder T.M. Preliminary report: intracranial cholinergic drug infusion in patients with Alzheimer's disease. Neurosurgery 1984, 15: 514-518.
140. Davis, K.L. \& Motts, R.C. Enhancement of memory ڤ processes in Alzheimer's disease with multiple dose intra- $Z$ venous physostigmine. Am J Psychiat 1982, 139: $\mathbb{\mathbb { Q }}$ $1421-1424$.

141. Peters, B.H. \& Levin, H.S. Effects of physostigmine and $\subseteq$ lecithin on memory in Alzheimer's disease. Ann Neurol 1979, 6: $219-222$.

142. Davidson, M., Zemischlany, Z., Mehs, R.C., Horvath, J.B., ఫ Powchik, P., Blass, J.P. \& Davis, K.L. 4-Aminopyridine in the treatment of Alzheimer's disease. Biol Psychiat 1988, 23: 485-490.

143. Bowman, W.C. Aminopyridines - their pharmacological actions and potential clinical uses. Trends Pharmacol Sci i) 1982, 3: $183-185$.

144. O'Brien, J.T., Eagger, S. \& Levy, R. Effects of tetrahydro- $\vec{O}$ aminoacridine on liver function in patients with Alzheimer's disease. Age Ageing 1991, 20: 129-131.

145. Forsyth, D.R, Surman, D.J., Morgan, R.A. \& Wilcox, G.K. Clinical experience with and side effects of tacrine hydrochloride in Alzheimer's disease: a pilot study. Age Ageing 1989, 18: 223-229.

146. Molloy, D.W., Gyatt, G.H., Wilson, D.B., Duke, R., Rees, L. \& Singer, J. Effect of tetrahydroaminoacridine in cogni- tion, function and behaviour in Alzheimer's disease. Can Med Assoc J 1991, 144: 29-34.

147. Rosenberg, D.R., Wright, B.A. \& Gershon, S. Cognitive $\vec{\circ}$ enhancing agents for the treatment of senile dementia of the Alzheimer type. Drugs Today 1990, 26: 447-449.

148. McLachlan, D.R.C., Dalron, A.J. \& Kruck, T.D.A. Intramuscular desferrioxamine in patients with Alzheimer's disease. Lancet 1991, 337: 1304-1308.

149. Huppert, F.A. Neuropsychological assessment of dementia. Rev Clin Gerontol 1991, 1: 159-169. 